\title{
137. New Type Imaging Plate(Vシリーズ)の物理特性 Basic Image Properties of New Type Imaging Plate (-V Series-)
}

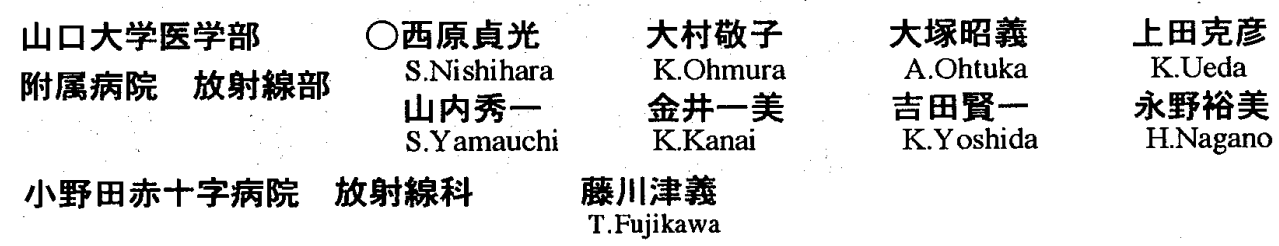

【目的】今回，新しいタイプのイメージングプレート(以下,IPとする.)としてVタイプが

\begin{tabular}{lcrcc} 
& \multicolumn{2}{c}{ ST } & \multicolumn{2}{c}{ HR } \\
& III $_{\mathrm{N}}$ & $\mathrm{V}$ & III N $^{*}$ & $\mathrm{~V}$ \\
\hline 輝尽発光量 & 100.0 & 107.2 & 100.0 & 81.3 \\
X線吸収率 $(x)$ & 44.9 & 49.5 & 68.1 & 62.2 \\
& $(100.0)$ & $(110.4)$ & $(100.0)$ & $(91.3)$
\end{tabular}

Table 1
市販された。そこでここの イプと従来の III $\mathrm{N}_{\mathrm{N}}$ の物理特性を調 ベ，比較したので報告する。

【方法】(1) 各IPの輝尽発光量 とX線吸収率を測定した。STに

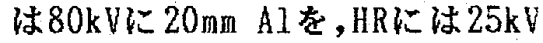
に6cm Acrylを付加した線質をを れぞ使用した。

(2) 各IPのプリサンプリングMTF

を测定した。

(3)各IPへの入射線量とディジタ
ルWS值の関係を調べるため，撮影条件: $80 \mathrm{kV}$ ，付加フイルタ： $20 \mathrm{mmAl}$,FFD: $260 \mathrm{~cm}$ で曝射時間を変え,入射線量を $0.13 \mu \mathrm{C} / \mathrm{kg}$ $(0.5 \mathrm{mR})$ から $3.61 \mu \mathrm{C} / \mathrm{kg}(14 \mathrm{mR})$ と変化させて, 各々のディジ タル测定した。

【結果と考察】(1)Table 1に各IPの輝尽発光量とX線吸収

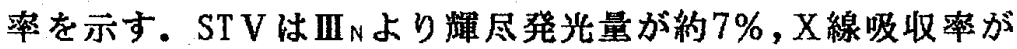
約 $10 \%$ 向上し，HR V は III に対して発光量が約 $20 \%$, 吸収率

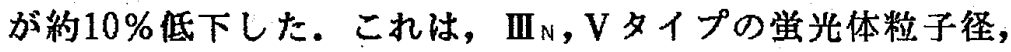
充填率や塗布量, 営光体表面の保護層などが異なるためだ と考える.

(2)Fig.1に各IPのプリサンプリングMTFを示す.ST,HRとも にMTFは III $\mathrm{N}$ V タイプでほほ等しくなっている. ST V は IIIN より感度が高いにもかかわらず,同等のMTFとなっているの は, 営光体粒子が微小化していることと蛍光体表面の保護 層が約4分の 1 となっているためと考元る。

(3)Fig.2とFig.3は，0.3cycle/mmと $3.0 \mathrm{cycles} / \mathrm{mm}$ の空間周 波数をパラメータとして, IPへの入射線量とディジタルWS 值の関你を示したグラフである.STの場合 (Fig.2),0.3cycle/mm

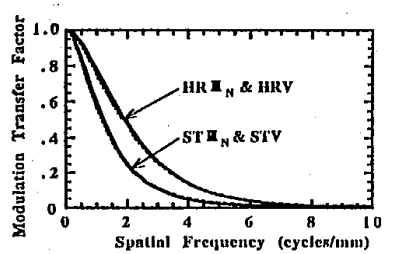

Fig. 1

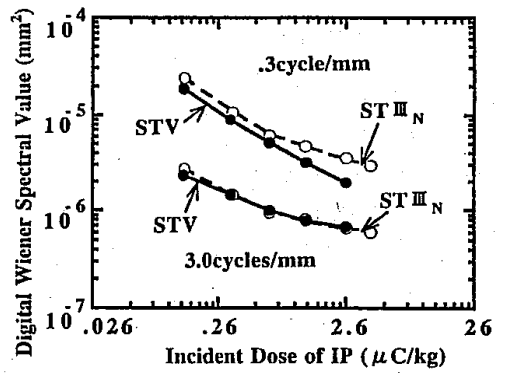

Fig.2 をみると,入射線量が少ないとき Vは四的よりディジタルWS 值は低い值を示す。これ付，Vの感度が而的より高いためで ある.また，線量が增すほ汇両者の差は大きくなっている。 これは営光体の微粒子化と充填率の増加により構造モトル が低下するためである. 3.0cycles/mmのとき，両者はほぼ 同等となっている.このことから,ST V は IIINより構造モト ルが良いといえる．Fig.3はHRの場合である． $0.3 \mathrm{cycle} / \mathrm{mm,}$ $3.0 \mathrm{cycles} / \mathrm{mm}$ の゙ちらの場合も約 $0.8 \mu \mathrm{C} / \mathrm{kg}$ (約 $3 \mathrm{mR}$ ) 以上で, HRVのほうが吕NよりもディジタルWS值は低い值となった。 この理由もSTと同棣に, 蛍光体の微粒子化と充填率の増加 によると考える.

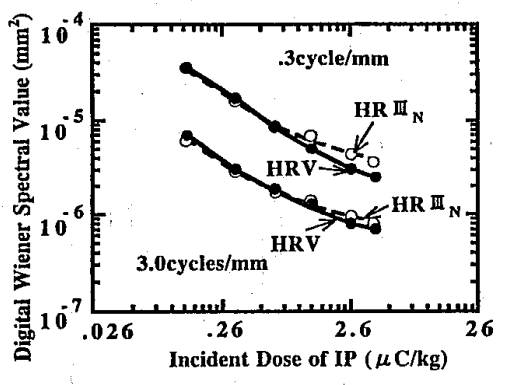

Fig.3 